\title{
Characterization of the Gene Encoding Pisatin Demethylase (FoPDA1) in Fusarium oxysporum
}

\author{
Jeffrey J. Coleman, ${ }^{1}$ Catherine C. Wasmann, ${ }^{1}$ Toshiyuki Usami, ${ }^{2}$ Gerard J. White, ${ }^{1}$ Esteban D. \\ Temporini, ${ }^{1}$ Kevin McCluskey, ${ }^{1}$ and Hans D. VanEtten ${ }^{1}$ \\ ${ }^{1}$ School of Plant Sciences, Division of Plant Pathology and Microbiology, Room 303 Forbes Building, University of Arizona, \\ Tucson 85721 U.S.A.; ${ }^{2}$ Graduate School of Horticulture, Chiba University, Matsudo, Chiba, 271-8510 Japan \\ Submitted 12 May 2011. Accepted 12 July 2011.
}

\begin{abstract}
The pea pathogen Fusarium oxysporum f. sp. pisi is able to detoxify pisatin produced as a defense response by pea, and the gene encoding this detoxification mechanism, FoPDA1, was $82 \%$ identical to the cytochrome $\mathbf{P 4 5 0}$ pisatin demethylase PDA1 gene in Nectria haematococca. A survey of F. oxysporum f. sp. pisi isolates demonstrated that, as in N. haematococca, the PDA gene of $F$. oxysporum f. sp. pisi is generally located on a small chromosome. In $N$. haematococca, PDA1 is in a cluster of pea pathogenicity $(P E P)$ genes. Homologs of these $P E P$ genes also were found in the $F$. oxysporum f. sp. pisi isolates, and $P E P 1$ and $P E P 5$ were sometimes located on the same small chromosomes as the FoPDA1 homologs. Transforming FoPDA1 into a pda ${ }^{-}$. oxysporum f. sp. lini isolate conferred pda activity and promoted pathogenicity on pea to some transformants. Different hybridization patterns of FoPDA1 were found in $F$. oxysporum f. sp. pisi but these did not correlate with the races of the fungus, suggesting that races within this forma specialis arose independently of FoPDA1. FoPDA1 also was present in the formae speciales lini, glycines, and dianthi of $F$. oxysporum but they had mutations resulting in nonfunctional proteins. However, an active FoPDA1 was present in $F$. oxysporum f. sp. phaseoli and it was virulent on pea. Despite their evolutionary distance, the amino acid sequences of FoPDA1 of $F$. oxysporum f. sp. pisi and $F$. oxysporum f. sp. phaseoli revealed only six amino acid differences, consistent with a horizontal gene transfer event accounting for the origin of these genes.
\end{abstract}

As a disease resistance mechanism, plants synthesize a variety of small-molecular-weight toxic compounds called phytoalexins in response to attack by pathogenic microbes. However, some microbial pathogens, particularly fungi, are able to

Current address for J. J. Coleman: Harvard Medical School, Massachusetts General Hospital, Division of Infectious Diseases, 55 Fruit Street, Gray Jackson 5, Room GRJ-504, Boston 02114, MA, U.S.A.

Current address for E. D. Temporini: Vilmorin Inc., 2551 N. Dragoon Street \#131, Tucson, AZ 85745, U.S.A.

Current address for K. McCluskey: Fungal Genetics Stock Center, School of Biological Sciences, University of Missouri-Kansas City, 64110, U.S.A.

Corresponding author: H. D. VanEtten; E-mail: vanetten@ag.arizona.edu; Telephone: +1.520.621.9355; Fax: +1.520.621.7186.

FoPDA1 = GenBank accession number AY487143.

* The $\boldsymbol{e}$-Xtra logo stands for "electronic extra" and indicates that three supplementary figures and three supplementary tables are published online.. avoid these resistance mechanisms by detoxifying the phytoalexins produced by their host plant (Morrissey and Osbourn 1999; VanEtten et al. 2001). Pea (Pisum sativum L.), for example, produces copious amounts of the phytoalexin $(+)$ pisatin in response to fungal infection and, although (+) pisatin is toxic to most fungi that are not pathogenic on pea, most fungal pathogens of pea are able to detoxify this compound and are tolerant of pisatin (Cruickshank 1962; Delserone et al. 1999).

Pisatin demethylase (pda), the enzyme responsible for detoxifying pisatin (Fig. 1), is a substrate-inducible cytochrome $\mathrm{P} 450$ best characterized in the ascomycetous fungus Nectria haematococca MPVI (anamorph Fusarium solani f. sp. pisi). Isolates of $N$. haematococca MPVI that are highly virulent on pea have pisatin demethylating activity $\left(\mathrm{Pda}^{+}\right)$and are more tolerant of pisatin than isolates lacking this activity $\left(\mathrm{Pda}^{-}\right)$(VanEtten et al. 1980). Transformation of a functional gene (PDA) for pda into a $\mathrm{Pda}^{-}$isolate increases both the tolerance of the isolate to pisatin and its virulence on pea (Ciufetti and VanEtten 1996). Conversely, disruption of a PDA gene in a $\mathrm{Pda}^{+}$isolate reduces the virulence of the isolate and its tolerance to pisatin (Wasmann and VanEtten 1996). This relationship between pda and the virulence of $N$. haematococca has led to the conclusion that pda is a host-specific virulence factor in this fungus.

Nine PDA genes have been identified in N. haematococca MPVI by classical genetics (Funnell et al. 2002; Kistler and VanEtten 1984a; Mackintosh et al. 1989; Miao and VanEtten 1992) and four PDA genes have been sequenced: PDAT9 (Maloney and VanEtten 1994), PDA6-1 (Reimmann and VanEtten 1994), PDA4 (K. Hirschi and H. D. VanEtten, unpublished), and PDA1-1 (cDNA) (Q. D. Wu and H. D. VanEtten, unpublished). Although the PDA genes are highly similar ( $>90 \%$ amino acid identity) to each other, they are sufficiently different from other cytochrome P450s to be placed in their own family (CYP57) (Maloney and VanEtten 1994). PDA gene products' high degree of specificity and biochemical affinity for pisatin, their association with high virulence on pea, and the tolerance of pisatin associated with these enzymes have led to the hypothesis that these cytochrome P450s make up a specialized detoxification system that arose during the evolution of $N$. haematococca as a pea pathogen (VanEtten et al. 1989).

A survey of other true fungi that are pathogens found that isolates with moderate to high virulence on pea rapidly demethylated pisatin (Delserone et al. 1999). However, an attempt to identify the PDA genes in other pea pathogens using the $P D A$ gene from $N$. haematococca as a probe in Southern hybridization showed that only DNA of the taxonomically related fungi $F$. oxysporum and Neocosmospora boninensis hybridized with the Nectria haematococca PDA gene probe (Delserone et al. 1999; Temporini and VanEtten 2004). 
The PDA1 gene of $N$. haematococca MPVI is located on a 1.6-Mb conditionally dispensable (CD) chromosome and is the only member of a cluster of genes involved in pea pathogenicity (PEP genes) with a known biochemical function (Han et al. 2001). The four genes in this cluster shown to contribute to virulence on pea (PDA1, PEP1, PEP2, and PEP5) in N. haematococca also have been shown to have orthologs in F. oxysporum f. sp. pisi, and at least two of these genes (FoPDA1 and PEPI) are within close proximity of one another in an isolate of $F$. oxysporum f. sp. pisi (Temporini and VanEtten 2004).

Whereas most pea-pathogenic fungi appear to have evolved a specific cytochrome $\mathrm{P} 450$ for detoxifying pisatin (George and VanEtten 2001), only in N. haematococca MPVI is there direct evidence that pda is associated with virulence (Ciuffetti and VanEtten 1996; Wasmann and VanEtten 1996). This article details the characterization of $P D A$ genes in F. oxysporum and, in particular, from $F$. oxysporum f. sp. pisi. The evidence presented here confirms that pisatin detoxification is a virulence factor for pea, with a major role in conferring the ability of pea-pathogenic fungi to cause disease on this plant.

\section{RESULTS}

\section{Identification and sequencing of FoPDA1 and FoPDAt.}

The gene corresponding to FoPDA 1 was isolated from a genomic lambda library of $F$. oxysporum f. sp. pisi isolate T415 (Table 1) by probing the library with the $P D A$ gene of $N$. haematococca. The coding region of FoPDA 1 is $1,738 \mathrm{bp}$ in length and contains intragenic regions at four locations (nucleotides 248 to 303,654 to $709,1,316$ to 1,368 , and 1,498 to 1,555) (Supplementary Fig. S1). The $5^{\prime}$ and $3^{\prime}$ boundaries of all four regions were identical to the canonical exon and intron splice sites observed for other filamentous fungi (Kupfer et al. 2004). The four predicted intragenic regions were located at the same positions as the four introns in PDAT9 (Maloney and VanEtten 1994). FoPDA1 is predicted to encode a protein of 505 amino acids that has $>85 \%$ identity to the amino acid sequence of PDAT9 from $N$. haematococca.

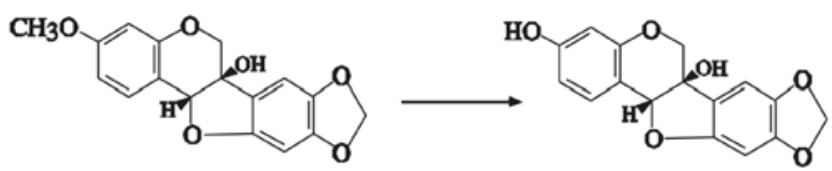

Fig. 1. Enzymatic detoxification of (+) pisatin catalyzed by pisatin demethylase.

Table 1. Fungal isolates used in this study

\begin{tabular}{|c|c|c|}
\hline Fungus & Isolate & Source $^{a}$ \\
\hline Nectria haematococca MPVI & $77-13-7, T-110,44-100$ & Our collection \\
\hline \multicolumn{3}{|c|}{ Fusarium oxysporum f. sp. pisi } \\
\hline Race 1 & $\begin{array}{l}\text { F28, F79, F109, F184, } \\
\text { F206 }\end{array}$ & Our collection \\
\hline Race 2 & $\begin{array}{l}\text { F26, F40, F69, F81, } \\
\text { F204, T415, T416 }\end{array}$ & Our collection \\
\hline Race 5 & F23, F202, F207 & Our collection \\
\hline Race 6 & F27, F105 & Our collection \\
\hline \multicolumn{3}{|l|}{ F. oxysporum } \\
\hline f. sp. aechaene & NRRL 22533 & K. O’Donnell \\
\hline f. sp. cubense & NRRL 26029 & K. O’Donnell \\
\hline f. sp. lini & NRRL 28932 & K. O’Donnell \\
\hline f. sp. lycopersici & NRRL 26383 & K. O’Donnell \\
\hline f. sp. batatas & NRRL 25594 & K. O’Donnell \\
\hline f. sp. glycines & NRRL 25598 & K. O’Donnell \\
\hline f. sp. melonis & NRRL 26406 & K. O’Donnell \\
\hline f. sp. phaseoli & NRRL 26761 & K. O’Donnell \\
\hline f. sp. dianthi & NRRL 28902 & K. O’Donnell \\
\hline
\end{tabular}

${ }^{a}$ K. O'Donnell, United States Department of Agriculture, Peoria, IL, U.S.A.
Previous Southern analyses using a fragment of the $N$. haematococca PDAT9 gene suggested the presence of at least two PDA genes in isolate T415 (Delserone et al. 1999; Temporini and VanEtten 2004). The second hybridizing fragment was cloned and sequenced and found to contain a truncated PDA gene, designated FoPDAt, with $99 \%$ nucleotide identity to FoPDA1. The $5^{\prime}$ end of the region of identity was located in the codon for residue M76 of FoPDA1. The similarity to FoPDA 1 ended 250 nucleotides $3^{\prime}$ of the coding region. No evidence of DNA sequence with similarity to the promoter region of FoPDA1 was found.

\section{Expression of pisatin demethylating activity in culture.}

The demethylation of pisatin by mycelium of $F$. oxysporum f. sp. pisi was characterized by a lag of approximately 1 to $2 \mathrm{~h}$ followed by rapid demethylation, which was complete by 4 to $6 \mathrm{~h}$ (Fig. 2). The addition of $1 \%$ glucose did not repress pisatin demethylation, as had been observed with $N$. haematococca (George and VanEtten 2001; Straney and VanEtten 1994; VanEtten and Barz 1981) but it did retard the onset and completion of demethylation by approximately $1 \mathrm{~h}$ (Fig. 2). Higher concentrations of glucose $(2$ and $5 \%)$ had effects similar to that of $1 \%$ glucose, in that demethylation was approximately 1 to $1.5 \mathrm{~h}$ slower than in the control without glucose (data not shown).

The accumulation of FoPDA1 mRNA in response to the addition of pisatin was measured by quantitative real-time polymerase chain reaction (PCR). The maximal amount of FoPDA1 mRNA was 670-fold of the basal level and occurred approximately $1 \mathrm{~h}$ after pisatin was added (Fig. 3 ). The induction of pisatin demethylating ability was characterized by a lag of approximately $2 \mathrm{~h}$ followed by a rapid rise in activity (Fig.

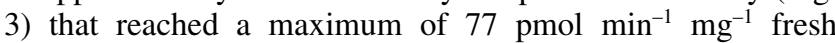
weight of mycelia approximately $6 \mathrm{~h}$ after the addition of pisatin and then declined. This pattern of induction of enzyme activity was similar to that observed with $P D A 1$ in $N$. haematococca; however, the FoPDA1 mRNA appeared to be induced more quickly than the PDA1 mRNA (George et al. 1998; Liu et al. 2003; Straney and VanEtten 1994).

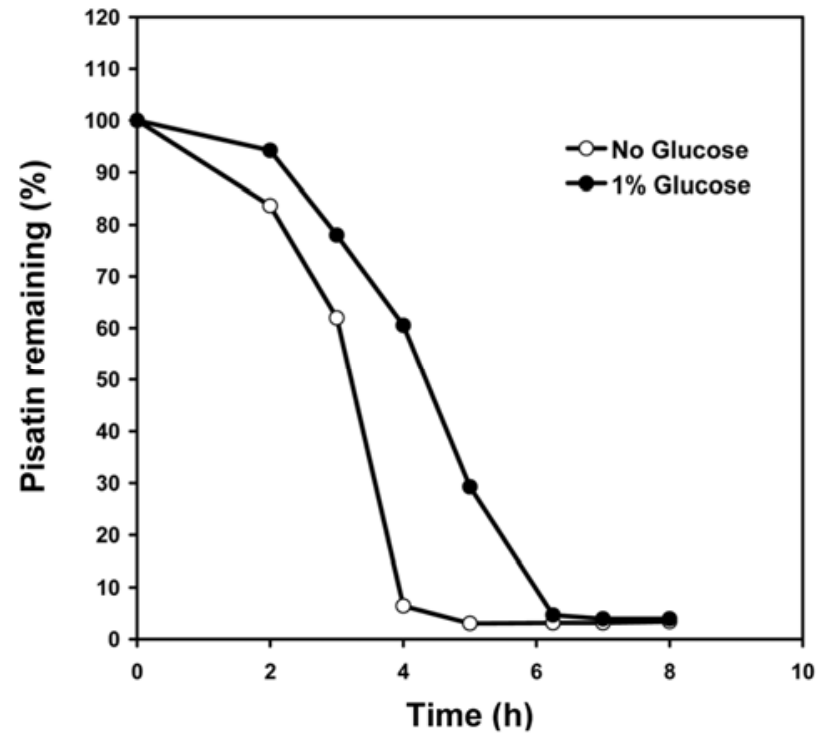

Fig. 2. Demethylation of pisatin by Fusarium oxysporum f. sp. pisi isolate T415 in the absence or presence of $1 \%$ glucose. Mycelial suspensions of $3.5 \mathrm{ml}$ were placed into $50-\mathrm{ml}$ flasks and $\left[{ }^{14} \mathrm{C}\right]$ pisatin $(300 \mathrm{dpm} / \mu \mathrm{g})$ dissolved in dimethyl sulfoxide (DMSO) was added to a final concentration of $0.1 \mathrm{mM}$ pisatin and $0.5 \%$ DMSO. At 1 - to 2 -h intervals, $0.5-\mathrm{ml}$ aliquots were withdrawn and analyzed for pisatin content. 
Four compounds, (+) maackiain, (+) methylmaackiain, methylformononetin, and 6-methoxy-1-tetralone, which are relatively effective inducers of pda activity in some fungal pathogens of pea other than N. haematococca (George and VanEtten, 2001) were tested for their ability to induce pda activity in isolate T415. None of the tested compounds induced pda to a greater extent than the solvent control, $0.5 \%$ dimethyl sulfoxide (DMSO) (Supplementary Table S1). The inability of these compounds to induce pda activity in $F$. oxysporum f. sp. pisi is similar to results from previous pda induction studies on $N$. haematococca (George and VanEtten 2001).

\section{Characterization of FoPDA1 as a PDA gene.}

In order to verify that the gene identified as FoPDA1 was responsible for the pda activity in $F$. oxysporum isolate T415, transformations to disrupt the FoPDA1 gene were attempted. The basic approach was to disrupt FoPDA1 by insertion of the $h p h$ gene (conferring resistance to hygromycin) into the coding sequence of FoPDA1 via homologous recombination. Several different plasmid constructs were used, resulting in a total of 905 hygromycin-resistant transformants; however, all of the transformants retained pda activity. Although there was a faint hybridizing fragment in the T415 digest in addition to FoPDAt (Fig. 4), we found no evidence of another PDA-like gene that could have made gene replacement difficult. The reasons for the lack of success to create a $\triangle F O P D A 1$ isolate are unknown.

As an alternative approach to demonstrate that FoPDA 1 is responsible for pda activity in $F$. oxysporum f. sp. pisi, the gene was transformed into 44-100, a Pda isolate of $N$. haematococca MPVI. The expression of PDA1 in N. haematococca is repressed in the presence of glucose but not in $F$. oxysporum f. sp. pisi, suggesting that the two promoters may differ in their regulatory characteristics (Fig. 2). In view of these presumed differences in the promoters of these two $P D A$ genes, a plasmid (pCW10071) was constructed in which FoPDA1 was un-

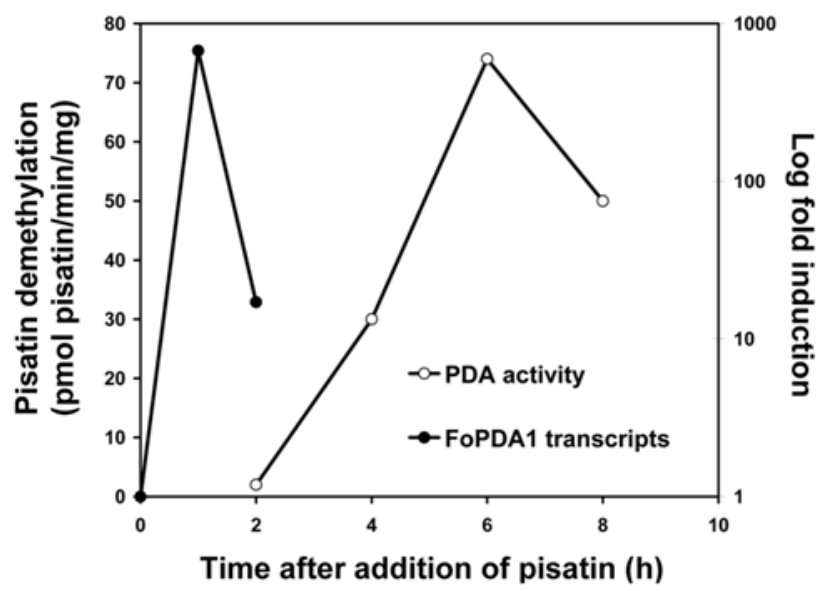

Fig. 3. Induction by pisatin of FoPDA1 mRNA and pisatin demethylase (pda) activity in Fusarium oxysporum f. sp. pisi isolate T415.

Table 2. Expression of pisatin demethylase (pda) activity by FoPDA1 in Nectria haematococca ${ }^{\mathrm{a}}$

\begin{tabular}{lc}
\hline Isolate & Pisatin remaining (\%) \\
\hline FoPDA1 under NhPDA1 promoter & 13.7 \\
77-13-7 (positive control) & 100 \\
$44-100$ (negative control) & 15.4 \\
$44-100$ NhPDA1 promoter: FoPDA1 & \\
\hline a Peptone-glucose agar medium $(0.25 \mathrm{ml})$ supplemented with $\left[{ }^{14} \mathrm{C}\right]$ pisatin \\
(31 $\mu$ g pisatin per $10,000 \mathrm{dpm}$ per $5 \mu \mathrm{l}$ of dimethyl sulfoxide per $1 \mathrm{ml}$ of \\
medium) was inoculated with each isolate and percent $\left[{ }^{14} \mathrm{C}\right]$ remaining \\
assayed after $96 \mathrm{~h}$.
\end{tabular}

der the control of the $N$. haematococca PDA1 promoter. Using pCW10071, a 44-100 transformant containing the NhPDA1 promoter::FoPDA1 chimera was generated, and this transformant had pda activity (Table 2).

\section{Distribution of homologs}

of FoPDA1 in F. oxysporum f. sp. pisi.

Seventeen isolates of $F$. oxysporum f. sp. pisi representing four physiologic races (races 1, 2, 5, and 6) (Table 1) were examined and all had pda activity and were pathogenic but showed some variability in their ability to produce necrotic lesions on the stems of 'Little Marvel' pea, which is susceptible to all of these races (Table 3) (Haglund and Kraft 1979). F. oxysporum f. sp. pisi is known as a wilt pathogen but it also produces tissue necrosis (Kerstin et al. 2002), and measurements of the necrotic lesions on pea stems have been used previously to assess the virulence of $F$. oxysporum $\mathrm{f}$. sp. pisi (Delserone et al. 1999). All of the isolates were subjected to Southern hybridization analysis (Fig. 4). In one gel, the fragments smaller than approximately $2 \mathrm{~kb}$ were run off the gel in order to resolve the larger DNA fragments (Fig. 4A), while a second gel was run for a shorter time to resolve the presence of DNA fragments of approximately 1 to $2 \mathrm{~kb}$ (Fig. 4B). All of the isolates surveyed contained at least one hybridizing fragment and, although common patterns of hybridization were found, they were not correlated with the race of the isolate. For example, isolates of different races (e.g., F206, F26, F23, and F27, which belong to races $1,2,5$, and 6 , respectively) had the same pattern of hybridization. Another group of isolates, which included members of race 1 (F28 and F184), race 2 (F69, F81, T415, and T416), and race 5 (F202 and F207), also displayed the same hybridization pattern. In addition, these latter isolates were the only ones that appeared to have FoPDAt because they had a hybridizing fragment of the same size as that for FoPDAt in

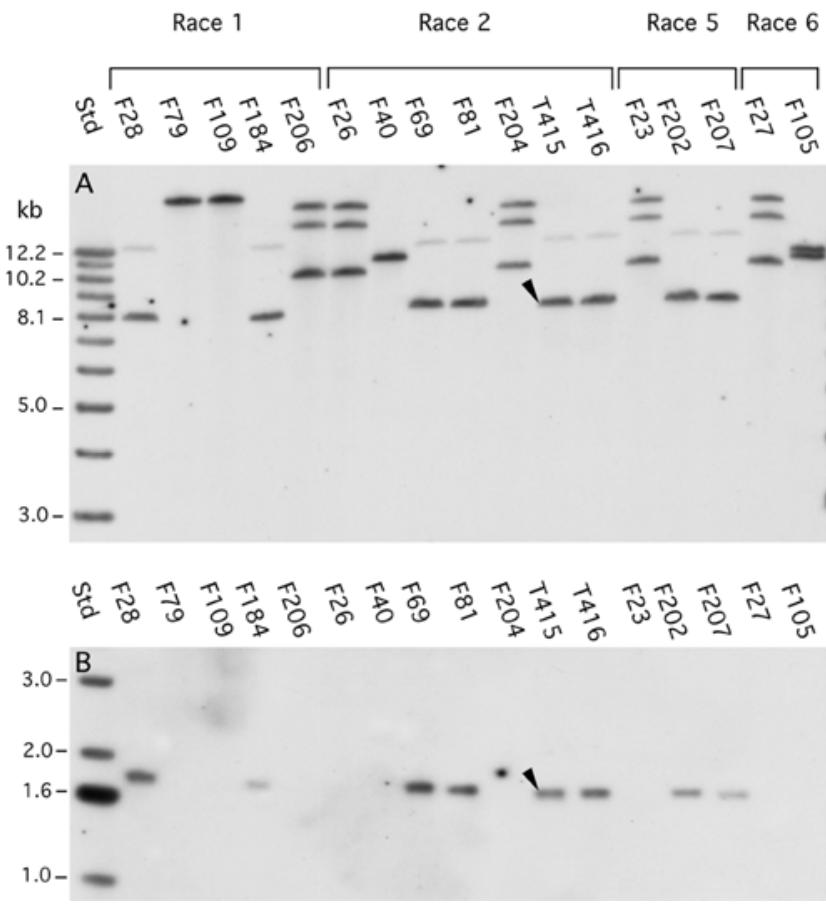

Fig. 4. Distribution of homologs of FoPDA1 in Fusarium oxysporum f. sp. pisi. Genomic DNA of the indicated isolate was digested with XhoI and probed with a 1-kb EcoRI-ClaI fragment of the promoter and N-terminal coding region of the FoPDA1 gene. Different gels were used to resolve A, the larger $(>8 \mathrm{~kb})$ fragments and $\mathbf{B}$, the smaller (1 to $2 \mathrm{~kb}$ ) fragments. Arrowheads denote the fragments that correspond to FoPDA1 and PDAt, respectively. 
T415. Isolates F79, F109, and F40 appeared to contain a single fragment hybridizing to the FoPDA1 homolog.

\section{Chromosomal location}

of FoPDA1 and other PEP genes in F. oxysporum f. sp. pisi.

Pulsed-field gel electrophoresis (PFGE) was utilized to ascertain the size of the chromosomes in different races of $F$. oxysporum $\mathrm{f}$. sp. pisi harboring FoPDA1 and the homologs of the other $P E P$ genes known to contribute to virulence in $N$. haematococca (PEP1, PEP2, and PEP5) (Fig. 5). As previously shown (Han et al. 2001), these genes were all found to be on a 1.6-Mb chromosome in the virulent isolate 77-13-7 of $N$. haematococca. Four of the seven $F$. oxysporum f. sp. pisi isolates (F28, F69, T415, and F202) also had FoPDA1, PEP1, and PEP5 located on the same relatively small (approximately $2.0 \mathrm{Mb}$ ) chromosome. In isolate F105, FoPDA1, PEP2, and $P E P 5$ were located on an approximately $2.3-\mathrm{Mb}$ chromosome; $P E P 1$ appeared to be absent in this isolate. Hybridization of FoPDA1, PEP1, and PEP5 in isolates F79 and F109 showed that the genes are located on different chromosomes and that FoPDA1, in particular, was located on a large chromosome. The size of the chromosome carrying FoPDA1 in isolates F79 and F101 is uncertain due to the lack of resolution in that portion of the PFGE analysis. The final gene, PEP2, may possibly

Table 3. Virulence of Fusarium oxysporum f. sp. pisi isolates on pea ('Little Marvel') $)^{\mathrm{a}}$

\begin{tabular}{lc}
\hline Isolate & Lesion length $(\mathbf{m m})$ \\
\hline Race 1 & \\
F28 & $3.8 \pm 0.7$ \\
F79 & $4.9 \pm 2.4$ \\
F109 & $5.9 \pm 0.9$ \\
F184 & $4.3 \pm 0.9$ \\
F206 & $13.7 \pm 1.9$ \\
Race 2 & \\
F26 & $8.5 \pm 1.4$ \\
F40 & $4.9 \pm 2.4$ \\
F69 & $4.3 \pm 1.5$ \\
F81 & $5.7 \pm 1.5$ \\
F204 & $3.9 \pm 1.8$ \\
T415 & $4.6 \pm 1.1$ \\
T416 & $6.1 \pm 1.7$ \\
Race 5 & \\
F23 & $13.2 \pm 1.4$ \\
F202 & $5.2 \pm 1.7$ \\
F207 & $6.2 \pm 1.0$ \\
Race 6 & \\
F27 & $6.7 \pm 1.4$ \\
F105 & $7.1 \pm 1.1$ \\
Nectria haematococca MPVI (77-13-7) & $15.3 \pm 5.2$ \\
\hline a Lesion lengths are the averages and based on eight plants scored 8 days \\
postinoculation.
\end{tabular}

be located on the same chromosome as one of the other PEP genes or FoPDA1 in isolates F79, F105, and F109.

\section{Distribution of FoPDA1}

within the $\boldsymbol{F}$. oxysporum species complex.

F. oxysporum f. sp. pisi belongs to a group of fungi collectively called the Fusarium oxysporum species complex (FOSC) which has been divided based on host range, resulting in over 120 different formae speciales (Di Pietro et al. 2003; Michielse and Rep 2009). The virulence of eight different formae speciales isolates of $F$. oxysporum was assessed on garden pea (Table 4; Fig. 6). F. oxysporum f. sp. lini, F. oxysporum f. sp. glycines, $F$. oxysporum f. sp. lycopersici, $F$. oxysporum $\mathrm{f}$. sp. cubense, and F. oxysporum f. sp. aechaene were all unable to cause any significant lesion in the pea stem virulence assay. However, F. oxysporum f. sp. dianthi and $F$. oxysporum f. sp. phaseoli were virulent on pea, causing lesions of a size similar to those of F. oxysporum f. sp. pisi T415. However, the lesions caused by $F$. oxysporum f. sp. dianthi were lighter in color (tan versus brown) (Table 4; Fig. 6).

Southern analysis of representatives of 10 formae speciales representing four clades within the FOSC was undertaken to identify the distribution of PDA homologs. As shown before, four isolates within the same clade as $F$. oxysporum f. sp. pisi showed the presence of a hybridizing DNA fragment (formae speciales glycines, lini, and dianthi) (Fig. 7; Supplementary Fig. S2) (Temporini and VanEtten 2004). Despite the presence of an apparent homolog of PDA in these other members of the F. oxysporum f. sp. pisi-containing clade, only isolates of the pea pathogen $F$. oxysporum $\mathrm{f}$. sp. pisi had pda activity. Previously, homologs of PEP1, PEP2, and PEP5 were identified in

Table 4. Virulence of various Fusarium oxysporum formae speciales isolates on pea ('Alaska 2B')

\begin{tabular}{lcc}
\hline & \multicolumn{2}{c}{ Average lesion length (mm) } \\
\cline { 2 - 3 } Isolate & Experiment 1 & Experiment 2 \\
\hline Nectria haematococca MPVI & & \\
77-13-7 & $8.6 \pm 1.0$ & $14.7 \pm 4.2$ \\
T-110/44-100 & 0.0 & $4.5 \pm 1.3$ \\
F. oxysporum & & \\
f. sp. pisi (T415) & $8.2 \pm 2.3$ & $11.5 \pm 3.2$ \\
f. sp. dianthi & $7.8 \pm 0.8$ & nd \\
f. sp. lini & 0.0 & $0.7 \pm 0.3$ \\
f. sp. glycines & 0.0 & nd \\
f. sp. phaseoli & $7.8 \pm 4.5$ & nd \\
f. sp. lycopersici & nd & $1.2 \pm 0.5$ \\
f. sp. cubense & nd & $0.9 \pm 1.1$ \\
f. sp. aechaene & nd & $1.1 \pm 1.0$ \\
\hline
\end{tabular}

${ }^{a}$ Lesion lengths are the averages of lesions produced on six to 10 pea plants scored 6 days postinoculation; $\mathrm{nd}=$ not determined.

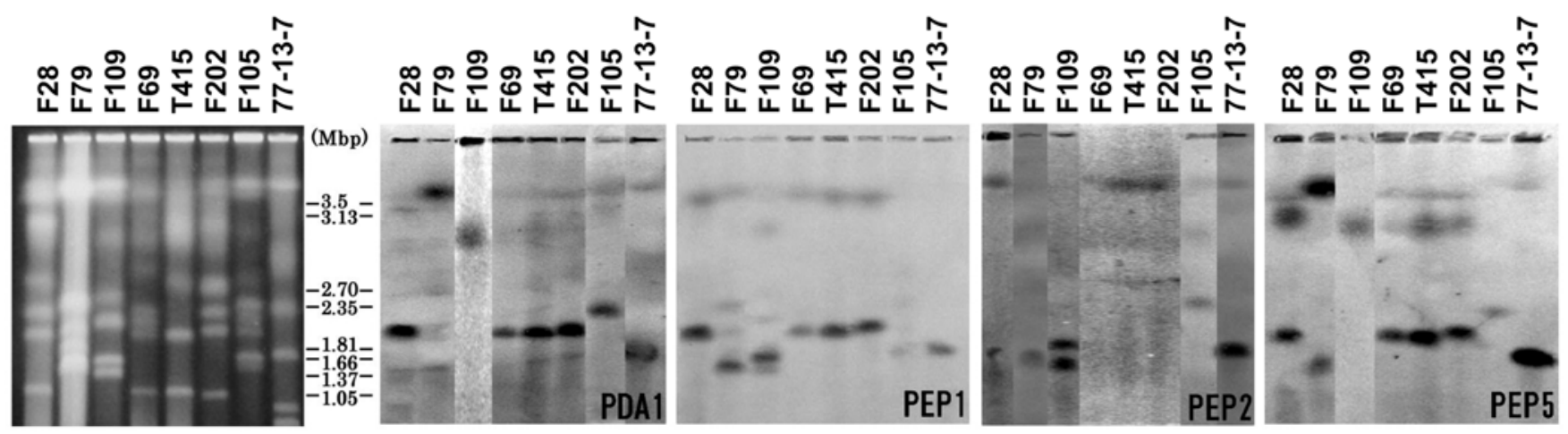

Fig. 5. Hybridization of FoPDA1 and orthologs of the pea pathogenicity (PEP) encoding genes to chromosomes of Fusarium oxysporum f. sp. pisi separated by pulsed-field gel electrophoresis. Isolates F28, F79, and F109 are race 1; F69 and T415 are race 2; F202 is race 5; and F105 is race 6. 
all the formae speciales included in the current studies ( $F$. oxysporum ff. spp. aechmeae, batatas, cubense, dianthi, glycines, lini, lycopersici, melonis, and phaseoli) (Temporini and VanEtten 2004; E. Temporini, unpublished).

The PDA loci of $F$. oxysporum ff. spp. glycines, lini, and dianthi were sequenced to determine why they lack pda activity. The PDA locus in F. oxysporum f. sp. lini has a $\mathrm{G}$ to A mutation at position 182 , changing the TGG tryptophan codon to a TAG stop codon. Overall, the FoPDA1 pseudogene in $F$. oxysporum f. sp. lini is $92.9 \%$ identical to FoPDA 1 in F. oxysporum f. sp. pisi. The premature stop codon results in a truncated protein 60 amino acids in length that is $91.7 \%$ (55 of 60) identical to the first 60 amino acids of FoPDA1 in F. oxysporum f. sp. pisi. The FoPDA1 gene of F. oxysporum f. sp. glycines has an 11-bp deletion starting at nucleotide 816 of the gene, resulting in a pseudogene $90.8 \%$ identical to FoPDA 1 in $F$. oxysporum f. sp. pisi. This pseudogene encodes a truncated protein 266 amino acids in length with similarity to FoPDA1 over the first 234 amino acids (94.9\% identity and $96.2 \%$ amino acid similarity). The FoPDA1 gene in $F$. oxysporum f. sp. dianthi is $99.8 \%$ identical to the FoPDA 1 pseudogene in F. oxysporum f. sp. glycines and contains the same 11-bp deletion found in $F$. oxysporum f. sp. glycines.

The only isolate outside of the clade containing $F$. oxysporum f. sp. pisi that had a $P D A$-hybridizing fragment is $F$. oxysporum f. sp. phaseoli (Fig. 7). Furthermore, F. oxysporum $\mathrm{f}$. sp. phaseoli was the only isolate within this survey, besides $F$. oxysporum f. sp. pisi, which had pda activity (Fig. 7). The two FoPDA 1 genes were $98.8 \%$ identical in nucleic acid sequence (1,721 of 1,742 bp), inclusive of all four conserved introns, resulting in six amino acid differences between the two FoPDA1 cytochrome P450 enzymes $(99.0 \%$ identity and $99.2 \%$ amino acid similarity).

The presence of an FoPDA1 gene or pseudogene within all members of the same clade as $F$. oxysporum f. sp. pisi supports the vertical inheritance of the gene within this clade. The high degree of identity between the FoPDA 1 pseudogenes of $F$. oxysporum $\mathrm{f}$. sp. glycines and $F$. oxysporum f. sp. dianthi suggests they have only recently begun to diverge, although the 11-bp deletion resulting in the inactivation of the gene occurred prior to the separation of these formae speciales. Phylogenetic analysis of the FoPDA 1 from $F$. oxysporum f. sp. phaseoli indicates that the gene is most closely related to FoPDA 1 from $F$. oxysporum f. sp. pisi (Fig. 8).
FoPDA1 is a virulence factor on pea.

Since attempts to disrupt FoPDAl in F. oxysporum f. sp. pisi were unsuccessful, FoPDA1 was placed in formae speciales isolates that were not pathogenic on pea to assess the role of FoPDA1 in virulence. Two different formae speciales were chosen, one within the same clade as $F$. oxysporum f. sp. pisi (F. oxysporum f. sp. lini) and one from a clade more evolutionarily distant ( $F$. oxysporum f. sp. lycopersici). As previously stated, neither of these isolates has pda activity; however, both of these isolates have homologs of PEP1, PEP2, and PEP5 (Temporini and VanEtten 2004). Transformation of the F. oxysporum f. sp. pisi FoPDA1 gene under its native promoter into either isolate resulted in transformants with pda activity (Sup-

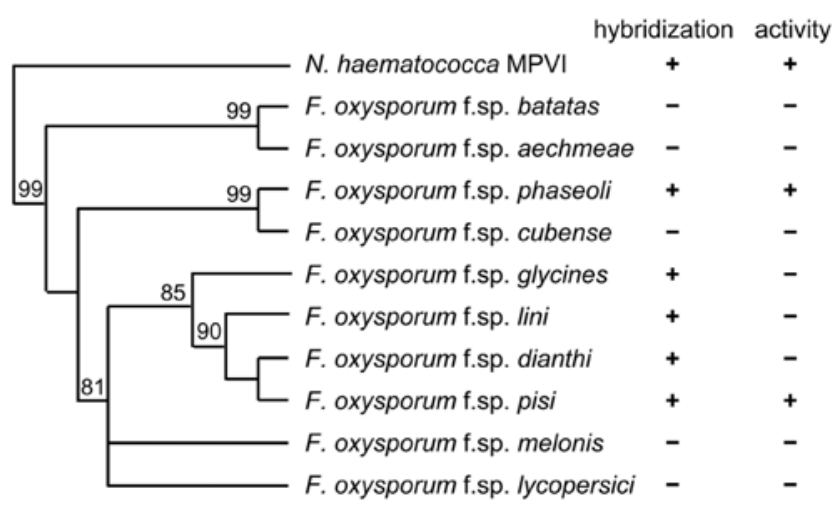

Fig. 7. Phylogenetic relationship between several Fusarium oxysporum formae speciales. Phylogenetic analysis was based on translation elongation factor $1 \alpha$. Presence of FoPDA1 as detected by hybridization and enzymatic activity is also denoted. Nectria haematococca was used as the outgroup.

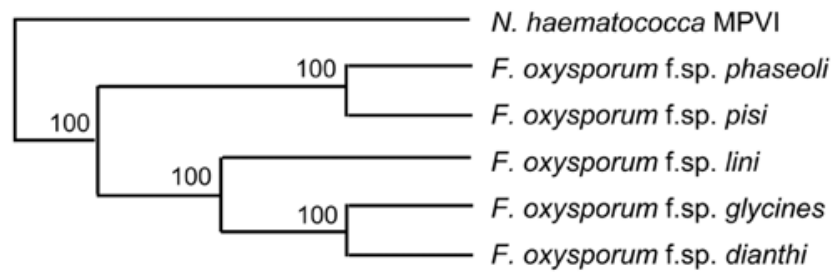

Fig. 8. Phylogenetic analysis of $P D A$ (pisatin demethylase) genes and pseudogenes from Fusarium oxysporum formae speciales. Nectria haematococca was used as the outgroup.

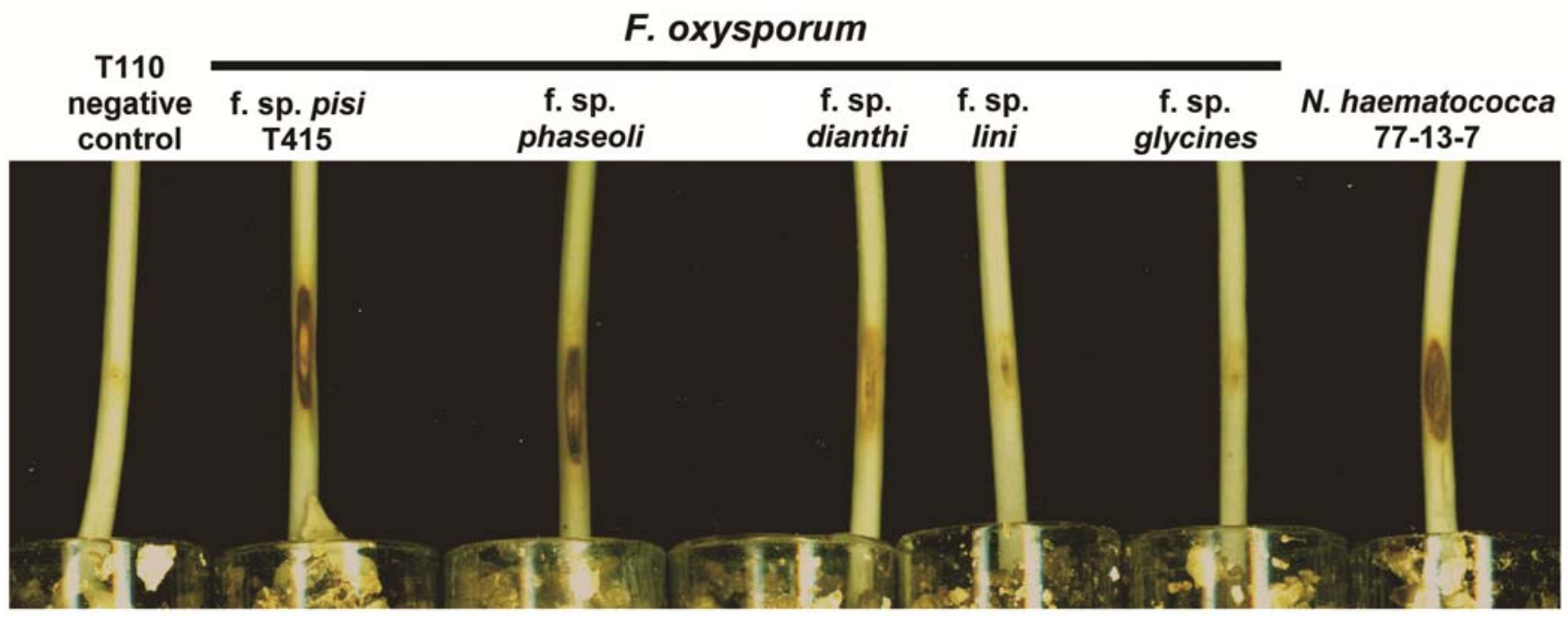

Fig. 6. Virulence of Fusarium oxysporum formae speciales on pea. From left to right: Nectria haematococca T110 (negative control), F. oxysporum f. sp. pisi (T415), F. oxysporum f. sp. phasesoli, F. oxysporum f. sp. dianthi, F. oxysporum f. sp. lini, F. oxysporum f. sp. glycines, and N. haematococca 77-13-7 (for comparison). 
plementary Table S2). Therefore, the transcription machinery necessary to recognize pisatin and to express pda is present in the two $\mathrm{Pda}^{-}$isolates. Several of the F. oxysporum f. sp. lini transformants not only expressed pda but were more virulent on pea stems than the recipient isolate, demonstrating that FoPDA1 is a virulence factor on pea (Table 5; Supplementary Fig. S3). None of the $F$. oxysporum f. sp. lycopersici isolates expressing FoPDA1 demonstrated increased virulence on pea (data not shown).

\section{DISCUSSION}

Because of the amino acid similarities between the PDA genes of $N$. haematococca and $F$. oxysporum f. sp. pisi, it would be expected that they share similar biochemical properties (substrate specificity, inhibitor sensitivity, and $\mathrm{K}_{\mathrm{m}}$ ), and preliminary experiments support this expectation (George 1998, George and VanEtten 2001). Likewise, they would be predicted to share similar regulatory properties. The two genes have similar induction specificity, because both are highly specific for pisatin as an inducer. In addition, the FoPDA1 promoter contains a 41-bp element with significant identity $(36 / 41$ bp; $87.8 \%$ ) to an element in the $N$. haematococca PDA1 promoter that confers pisatin-responsiveness (Khan et al. 2003). However, the lack of glucose repression suggests a distinct difference between these promoters. Prior studies by Khan and Straney (1999) had identified a region between -287 and -429 $\mathrm{bp}$, relative to the start of transcription, which mediated repression by glucose in culture independent of pisatin induction. This region of the promoter is different in FoPDA 1 and could explain the lack of glucose repression, although consensus binding sites for the glucose repressor CreA, similar to those observed in the promoter of PDA1 of N. haematococca (Khan and Straney 1999), are present in the FoPDA1 promoter. Since F. oxysporum f. sp. pisi is normally a wilt pathogen and proliferates in the sugar-poor xylem, it is difficult to speculate on what advantage the lack of glucose repression might have for F. oxysporum f. sp. pisi, although the persistence within this sugar-limited environment may have contributed to the lack of glucose repression.

The FoPDA1 gene was shown to function as a virulence gene by transforming it into a $\mathrm{Pda}^{-}$isolate. The variability in the degree of virulence obtained when FoPDA1 was placed into $F$. oxysporum f. sp. lini might be explained by positional effects of integration of the gene. A similar variability in virulence was observed when PDA1 was placed into a nonpathogenic isolate of $N$. haematococca MPVI (Ciuffetti and VanEtten 1996). Regardless, all of the F. oxysporum f. sp. lini FoPDA1 transformants with pda activity produced a significantly larger and more necrotic lesion on pea (Table 5) than the wild-type $F$. oxysporum $\mathrm{f}$. sp. lini isolate and the $\mathrm{Pda}^{-}$transformant (Table 5). The increased virulence of $F$. oxysporum $\mathrm{f}$. sp. lini transformants compared with $F$. oxysporum f. sp. lycopersici transformants also demonstrated that other virulence factors exist, which are common to $F$. oxysporum f. sp. lini and $F$. oxysporum f. sp. pisi but absent from the more distantly related $F$. oxysporum f. sp. lycopersici.

In $N$. haematococca MPVI, the gene encoding the cytochrome P450 PDA1 resides within a cluster of genes for pathogenicity on pea (the PEP cluster) that is located on a small CD chromosome, and all of the pea-pathogenic $N$. haematococca MPVI isolates examined have all of the PEP genes (Temporini and VanEtten 2002). As has been seen previously in $F$. oxysporum, there was considerable chromosome polymorphism (Ma et al. 2010) but, in F. oxysporum f. sp. pisi, FoPDA1 often was found together with at least one $P E P$ gene on a small chromosome (Fig. 5). However, it was rare for all of the $P E P$ genes known to be involved in virulence (PEP1, PEP 2, and $P E P 5)$ along with FoPDA1 to be on the same chromosome in F. oxysporum f. sp. pisi.

The pathogenic race of some $F$. oxysporum formae speciales has been associated with more than one clonal lineage, suggesting multiple origins for a single race (Baayen et al. 2000; Gordon and Martyn 1997; O'Donnell et al. 1998, 2009). The hybridization patterns of FoPDA1 from multiple races of $F . o x$ ysporum f. sp. pisi are consistent with the theory of multiple origins for the pathogenic races. In addition to the identical Southern hybridization pattern of eight isolates from races 1, 2 , and 5 , these also are the only surveyed isolates that harbor PDAt (Fig. 4). When a subgroup [F28 (race 1), F69 and T415 (race 2), and F202 (race 5)] of these isolates was selected for PFGE analysis, all carried FoPDA1, PEP1, and PEP5 on an approximately $2.0-\mathrm{Mb}$ chromosome (Fig. 5). Although the degree of similarity among these chromosomes from the different isolates is not known, these hybridization studies suggest that the chromosomes may share a common ancestor, despite their belonging to different pathogenic races.

The polyphyletic nature of $F$. oxysporum $\mathrm{f}$. sp. pisi has been observed by multilocus sequence typing, where strains of $F$. oxysporum f. sp. pisi have been assigned into at least $10 \mathrm{se}-$ quence types (ST) (O'Donnell et al. 2009). Of these 10 types, F. oxysporum ff. spp. pisi, lini, and dianthi can all be found in a single group, ST 90 (O'Donnell et al. 2009), suggesting that FoPDA1 has been retained within this group, albeit not always functional. However, the presence of a functional FoPDA 1 gene in $F$. oxysporum f. sp. phaseoli was unexpected. Although FoPDA 1 may have been retained from the last common ancestor of $F$. oxysporum f. sp. phaseoli and the clade containing $F$. oxysporum ff. spp. pisi, lini, glycines, and dianthi (followed by gene loss in the other formae speciales), a more parsimonious explanation would be that a horizontal transfer event occurred between the two lineages that retain a functional PDA gene. A horizontal gene transfer (HGT) event in F. oxysporum f. sp. phaseoli is supported by several other lines of evidence. As

Table 5. Virulence of Fusarium oxysporum f. sp. lini transformants harboring FoPDA1 on pea ${ }^{\mathrm{a}}$

\begin{tabular}{|c|c|c|c|c|c|c|c|c|c|}
\hline \multirow[b]{2}{*}{ Isolate } & \multirow[b]{2}{*}{$\mathbf{P D A}^{\mathbf{b}}$} & \multicolumn{6}{|c|}{ Average lesion length (mm) } & \multirow[b]{2}{*}{ Variance } & \multirow[b]{2}{*}{$t^{\mathrm{c}}$} \\
\hline & & Exp. 1 & Exp. 2 & Exp. 3 & Exp. 4 & Exp. 5 & Exp. mean & & \\
\hline F. oxysporum pisi & + & $13.0 \pm 2.3$ & $7.3 \pm 2.2$ & $10.8 \pm 2.0$ & $11.9 \pm 4.3$ & $11.5 \pm 1.5$ & $10.9 \pm 2.2$ & & $\ldots$ \\
\hline F. oxysporum lini & - & $3.4 \pm 1.1$ & $2.7 \pm 1.0$ & $5.2 \pm 2.0$ & $5.8 \pm 0.8$ & $3.0 \pm 1.6$ & $4.0 \pm 1.4$ & 4.13 & $\ldots$ \\
\hline $\operatorname{Tr} 1$ & + & $7.4 \pm 1.2$ & $5.4 \pm 2.0$ & $4.0 \pm 1.7$ & $3.4 \pm 1.3$ & $6.0 \pm 1.9$ & $5.2 \pm 1.6$ & 2.55 & 1.04 \\
\hline $\operatorname{Tr} 2$ & + & $6.2 \pm 1.7$ & $4.3 \pm 2.8$ & $6.6 \pm 1.4$ & $5.6 \pm 1.0$ & $6.3 \pm 2.1$ & $5.8 \pm 0.9$ & 0.84 & $1.81 * *$ \\
\hline $\operatorname{Tr} 3$ & + & $7.0 \pm 2.4$ & $4.5 \pm 2.0$ & $7.2 \pm 1.7$ & $6.3 \pm 2.0$ & $5.7 \pm 1.0$ & $6.1 \pm 1.1$ & 1.20 & $2.05^{*}$ \\
\hline $\operatorname{Tr} 16$ & - & $3.1 \pm 1.0$ & $2.6 \pm 1.7$ & $5.5 \pm 1.9$ & $5.6 \pm 0.7$ & $4.3 \pm 2.2$ & $4.2 \pm 1.4$ & 1.86 & 0.19 \\
\hline
\end{tabular}

${ }^{a}$ Virulence assays were conducted on seven to 10 pea plants ('Alaska 2B'), with the exception of experiment (Exp.) 3, which was conducted on six pea plants ('Little Marvel'). Lesions were scored 6 days postinoculation.

${ }^{\mathrm{b}} \mathrm{PDA}=$ pisatin demethylase.

${ }^{\mathrm{c}} t$ Values are based on a paired difference test based on the pooled estimate of the common variance compared with the $F$. oxysporum f. sp. lini control. Critical value for $t_{0.05}=1.86$ and $t_{0.10}=1.40 ; *$ and ** indicate values statistically significant for $t_{0.05}$ and $t_{0.10}$, respectively. 
mentioned previously, there were only six amino acid differences in the $F$. oxysporum $\mathrm{f}$. sp. phaseoli and $F$. oxysporum $\mathrm{f}$. sp. pisi FoPDA1 genes, and the high degree of conservation between these genes suggests that they have only recently diverged (Fig. 8). HGT of small chromosomes between different F. oxysporum formae speciales isolates has also been observed experimentally (Ma et al. 2010). In that study, one of the transferred chromosomes contained genes involved in virulence on tomato and conferred that virulence to the recipient isolate, which was originally nonpathogenic on tomato. This observation may explain the polyphyletic nature of host virulence and the emergence of new pathogenic lineages among members of the FOSC. If the FoPDA1 gene (and possibly the entire chromosome) from an isolate of $F$. oxysporum $\mathrm{f}$. sp. pisi were laterally transferred into $F$. oxysporum f. sp. phaseoli, it would demonstrate that HGT occurs in the environment and may have facilitated the abrupt expansion of host range among isolates of the FOSC. In additional support of HGT, $F$. oxysporum f. sp. phaseoli has been placed into ST 51 and ST 93, two ST in which $F$. oxysporum f. sp. pisi have also been found (O'Donnell et al. 2009), suggesting that, if an HGT event did occur with FoPDA1, it was prior to the divergence of $F$. oxysporum f. sp. pisi and $F$. oxysporum f. sp. phaseoli. Alternatively, because formae speciales are assigned based on the host plant on which they cause disease, the ability of $F$. oxysporum f. sp. phaseoli to cause disease on pea allows speculation that F. oxysporum ff. spp. phaseoli and pisi are, in fact, a single forma specialis, which is supported by the similar PDA genes in these two fungi.

This study confirms the importance of PDA in detoxifying pisatin and in conferring virulence on pea in a fungal species other than $N$. haematococca MPVI. The nucleotide similarity between PDA1 in N. haematococca and FoPDA1 in F. oxysporum $\mathrm{f}$. sp. pisi suggests that they share a common origin, although different regulatory mechanisms have evolved in the two pathogens. As in N. haematococca, FoPDA1, PEP1, and $P E P 5$ reside primarily on the same small chromosome in $F$. oxysporum f. sp. pisi. The presence of a functional FoPDA1 gene in $F$. oxysporum $\mathrm{f}$. sp. phaseoli, which has a high degree of similarity to FoPDA 1 in $F$. oxysporum f. sp. pisi, suggests that it may have been acquired recently by HGT and may be an example of host range expansion by HGT in nature; or, alternatively, that some isolates of $F$. oxysporum ff. spp. phaseoli and pisi are, in fact, a single forma specialis.

\section{MATERIALS AND METHODS}

\section{Chemicals.}

The chemicals $(+)$ pisatin, $(+)$ maackiain, methyl formononetin, (+) methyl maackiain, 6-methoxy-1-tetralone, and 3-Omethy- $\left[{ }^{14} \mathrm{C}\right]$ pisatin $\left(\left[{ }^{14} \mathrm{C}\right]\right.$ pisatin) were obtained as described by George and associates (1998); and 2,5-diphenyloxazole (PPO) was obtained from Research Products International (Mt. Prospect, IL, U.S.A.).

\section{Strains and growth conditions.}

F. oxysporum f. sp. pisi isolate JI 2 was obtained from the John Innes Institute (Norwich, U.K.) and is referred to as isolate T415 in this publication. Isolates used in this study are listed in Table 1. N. haematococca Berk. \& Broome isolates 77-13-7 and 44-100 are the products of laboratory crosses (Kistler and VanEtten 1984a). Isolate 77-13-7 contains a single PDA gene (PDA1), which has been characterized biochemically in the closely related isolate 77-13-4 (George and VanEtten 2001; George et al. 1998). Isolate 44-100 is $\mathrm{Pda}^{-}$(Kistler and VanEtten 1984a). Stock cultures were grown on V8 juice agar in petri plates or in tubes as slant cultures (medium 29) (Stevens
1974) at room temperature under ambient fluorescent lighting and stored at $4{ }^{\circ} \mathrm{C}$. For long-term storage, suspensions of conidia in 25 to $50 \%$ glycerol were stored at $-80^{\circ} \mathrm{C}$.

To obtain mycelium, 100 to $250 \mathrm{ml}$ of liquid medium were inoculated with conidia (approximately $10^{5}$ conidia $/ \mathrm{ml}$ ) and incubated for 12 to $40 \mathrm{~h}$ on a gyro-rotary shaker $(180 \mathrm{rpm})$ at room temperature. The mycelia were collected by vacuum filtration through Whatman number 4 filter paper (Whatman Inc., Piscataway, NJ, U.S.A.).

Escherichia coli DH5 $\alpha$ (Invitrogen Life Technologies, Valencia, CA, U.S.A.) was used for amplifying recombinant plasmids. The Lambda library was packaged and amplified using the nonpermissive E. coli XL1-Blue MRA (P2) (Stratagene, La Jolla, CA, U.S.A.). For screening, the library was plated using the permissive strain XL1-Blue MRA (Stratagene). For DNA isolation, Lambda $72(\lambda 72)$ was amplified in the permissive $E$. coli LE392.

\section{Genomic Southern hybridization analysis.}

Mycelium for the extraction of genomic DNA was produced as described above by growth in glucose asparagine medium (VanEtten et al. 1980) for 3 to 4 days. The mycelia were lyophilized and DNA was extracted from the mycelia as described by Miao and associates (1991).

For Southern hybridization, equal amounts $(3 \mu \mathrm{g})$ of genomic DNA were digested with restriction endonucleases. The DNA fragments were separated by electrophoresis in an agarose gel and transferred to nylon membranes (Hybond $\mathrm{N}^{+}$; GE Healthcare Bio-Sciences, Piscataway, NJ, U.S.A.) according to standard protocols (Sambrook and Russell 2001). DNA blots were probed with a $1.1-\mathrm{kb}$ EcoRI-ClaI or a $1.15-\mathrm{kb} S s t \mathrm{I}-B a m \mathrm{HI}$ fragment of FoPDA1. The synthesis of the probes and the detection of hybridization followed the procedure for chemiluminescent Southern hybridizations described by Wasmann and VanEtten (1996). Southern hybridization detection of FoPDA1 in the other formae speciales of $F$. oxysporum was conducted by digesting the genomic DNA with EcoRV and probing with a fragment of PDA1 from $N$. haematococca as previously described (Temporini and VanEtten 2002, 2004).

\section{Cloning and sequence analysis of FoPDA1 and FoPDAt.}

FoPDA1 was isolated from a Lambda library constructed in Lambda EMBL3 using the Lambda EMBL3/BamHI Vector Kit and the instructions supplied by the manufacturer (Stratagene). The library was screened with the 1.4-kb SacI fragment (SacB fragment) of the PDAT9 gene of $N$. haematococca (Maloney and VanEtten 1994). One clone, $\lambda 72$, was the source of the FoPDA1 gene. A $4.5-\mathrm{kb}$ SpeI-PstI fragment of $\lambda 72$ containing the entire FoPDA1 gene was identified by Southern hybridization with the SacB fragment as a probe, cloned into pBluescript II KS to give p04987, and sequenced.

FoPDAt was isolated from an ordered genomic sublibrary of isolate T415. Briefly, $25 \mu \mathrm{g}$ of PstI-digested genomic DNA was separated by electrophoresis and the portion of the gel containing fragments of 5.8 to $6.5 \mathrm{~kb}$ (the size range that hybridized with the 1.15-kb SstI-BamHI fragment of FoPDA1 used as a probe) was excised. The DNA fragments were purified using the QAIEX Gel Extraction Kit (Qiagen, Valencia, CA, U.S.A.) according to the manufacturer's instructions and cloned into pBluescript II KS. The sublibrary was ordered in 96-well microtiter plates, blotted to nylon membranes, and probed with the $1.15-\mathrm{kb}$ SstI-BamHI fragment of FoPDA1. One hybridizing clone, 39D7, was selected for sequencing.

Homologs of FoPDA1 from the other $F$. oxysporum formae speciales were amplified from genomic DNA by PCR using the primers FoPDA-2F and FoPDA-5R (Supplementary Table $\mathrm{S} 3$ ). The PCR product was T-A cloned into pCR (Invitrogen), 
transformed into $\mathrm{DH} 5 \alpha$, and screened for the insert of expected size (1,873 bp in isolate T415). Plasmid inserts representing each of the FoPDA1 homologs from the other $F$. oxysporum formae speciales were selected for sequencing.

DNA sequencing was performed by the DNA Sequencing Facility (Genetic Analysis and Technology Core of the Arizona Research Laboratories Division of Biotechnology, University of Arizona, Tucson, U.S.A.).

\section{Determination of the effects of glucose and other compounds on the metabolism of pisatin in culture.}

Mycelium was produced from cultures grown in glucoseyeast extract medium (VanEtten and Barz 1981) as described above and by George and VanEtten (2001), with the exception that cultures of isolate T415 were grown for $40 \mathrm{~h}$. Mycelia were suspended in $0.05 \mathrm{mM}$ potassium phosphate buffer $(\mathrm{pH} 6.5)$, rather than sodium phosphate buffer, at a ratio of $30 \mathrm{mg} \mathrm{ml}^{-1}$ (fresh weight) with or without $1 \%$ glucose. Aliquots of $3.5 \mathrm{ml}$ were placed into $50-\mathrm{ml}$ Erlenmeyer flasks and $\left[{ }^{14} \mathrm{C}\right]$ pisatin $(300$ $\mathrm{dpm} / \mu \mathrm{g}$ ) dissolved in DMSO was added to a final concentration of $0.1 \mathrm{mM}$ pisatin and $0.5 \%$ DMSO. The flasks were incubated at $25^{\circ} \mathrm{C}$ and $100 \mathrm{rpm}$. At 1- to 2-h intervals, $0.5-\mathrm{ml}$ aliquots were withdrawn for the analysis of pisatin content.

To test the ability of different compounds to induce pda activity, suspensions of mycelia in potassium phosphate buffer were prepared as above. The test compounds in DMSO were added to a final concentration of $0.1 \mathrm{mM}$ and $0.5 \%$ DMSO. A time course of pisatin demethylation induced by pisatin was performed concurrently in order to determine when to measure pda activity in the treated samples, which was normally 4.5 to $6 \mathrm{~h}$ after the addition of the test compound. The rate of pisatin demethylation was determined by adding $\left[{ }^{14} \mathrm{C}\right]$ pisatin (final concentration $0.1 \mathrm{mM}$ ) to $3.5 \mathrm{ml}$ of culture, and aliquots of 0.5 ml were withdrawn at $5,10,15$, and 20 min postinoculation and assayed for pisatin content. Each compound was tested at least twice, except for maackiain, which was tested once.

The amount of $\left[{ }^{14} \mathrm{C}\right]$ pisatin in samples was determined by adding the samples to $4.5 \mathrm{ml}$ of scintillation cocktail $(0.5 \%$ PPO in toluene) and using a Beckman LS6000SC Scintillation Counter (Beckman Instruments, Palo Alto, CA, U.S.A.) to record the $\left[{ }^{14} \mathrm{C}\right]$ (George and VanEtten 2001).

\section{Measurement of FoPDA1 expression by quantitative real-time PCR.}

Conidia of isolate T415 were incubated in $100 \mathrm{ml}$ of potato dextrose broth (PDB) (PhytoTechnology Laboratories, Shawnee Mission, KS, U.S.A.) for $12 \mathrm{~h}$ on a gyro-rotary shaker at room temperature as previously described. Mycelia were collected and suspended at a ratio of $30 \mathrm{mg} / \mathrm{ml}$ in $50 \mathrm{ml}$ of PDB and dispensed into $125-\mathrm{ml}$ Erlenmeyer flasks. Cultures were incubated for $30 \mathrm{~min}$ at room temperature on a gyro-rotary shaker and (+) pisatin in DMSO was then added to a final concentration of pisatin at $50 \mu \mathrm{g} / \mathrm{ml}$ and $1 \%$ DMSO. The control culture received DMSO to a final concentration of $1 \%$. Aliquots of the suspension were removed at 1,2 , and $4 \mathrm{~h}$ after the addition of $(+)$ pisatin and lyophilized.

Total RNA was extracted from lyophilized mycelia using the RNeasy plant mini kit (Qiagen) and suspended in RNase-free water. Contaminating DNA was removed using the GenHunter MessageClean kit (GenHunter, Nashville, TN, U.S.A.), and the concentration of the total RNA was determined using a NanoDrop 2000 spectrophotometer (Thermo Scientific, Wilmington, DE, U.S.A.). Complementary DNA (cDNA) was generated using SuperScript II reverse transcriptase (Invitrogen) with oligo-dT (Invitrogen) according to the manufacturer's protocol.

For PCR, the SYBR Green PCR Master mix (Invitrogen) and gene-specific primers were used. The number of transcripts of the $\beta$-actin gene was used to normalize the number of transcripts of FoPDA1. The primers for $\beta$-actin and FoPDA1 were those used by Liu and associates (2003) to analyze the expression of the PDA1 gene of $N$. haematococca. Quantitative realtime PCR was performed in an ABI PRISM 7000 sequence detection system (Applied Biosystems, Foster City, CA, U.S.A.) and the data compared using the algorithm $X=2^{-\Delta \Delta \mathrm{Ct}+\mathrm{SPE}}$ as described by Livak and Schmittgen (2001).

\section{PFGE and Southern hybridization analysis.}

Protoplasts of $F$. oxysporum were generated as previously described (Temporini and VanEtten 2002) and suspended in agarose at a density of $4 \times 10^{8}$ protoplasts $/ \mathrm{ml}$ using the first method described by Orbach and associates (1988). A Bio-Rad CHEF-DRIII system (Bio-Rad, Hercules, CA, U.S.A.) was used with $0.8 \%$ of certified megabase agarose (Bio-Rad), $1 \times$

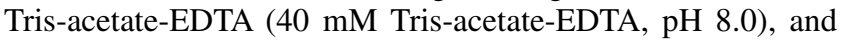
the following running conditions: $3.0 \mathrm{~V} / \mathrm{cm}$ for $48 \mathrm{~h}$ at $14^{\circ} \mathrm{C}$, a switch time of $500 \mathrm{~s}$, and a pulse angle of $106^{\circ}$. After PFGE, the agarose gel was soaked in $0.25 \mathrm{M} \mathrm{HCl}$ for $15 \mathrm{~min}$ and 0.4 $\mathrm{M} \mathrm{NaOH}$ for $30 \mathrm{~min}$. Chromosomal DNA was capillary transferred to a positively charged nylon membrane (Roche, Indianapolis, IN, U.S.A.). The DIG DNA Labeling and Detection Kit (Roche) was used for probe labeling, hybridization, and probe detection. Hybridization to DNA probes was performed at $60^{\circ} \mathrm{C}$. DNA fragments used as probes for FoPDA1, PEP1, $P E P 2$, and PEP5 were described previously (Temporini and VanEtten 2004).

Plasmid for the expression of FoPDA1 in N. haematococca.

The construct for the expression of FoPDA1 under the control of the $N$. haematococca PDA1 promoter (pCW10071) was made in the following manner. The plasmid pD1-XS (Straney and VanEtten 1994) (unpublished), which contains a 1.2-kb XhoI-SacI fragment with the promoter and $40 \mathrm{bp}$ of the amino acid coding region of PDA1, was digested with HindIII, the ends were filled in with the large fragment of DNA Polymerase I, and the plasmid digested with SstI. The resulting 1.2$\mathrm{kb}$ promoter fragment was ligated with pUC19 that was previously digested with SmaI and SstI to create pCW04071. To create pCW10071, the BamHI-SstI fragment from pCW04071 containing the promoter and $39 \mathrm{bp}$ of the coding region of $P D A 1$ and an SstI-NotI fragment of pCW07071 containing the FoPDA 1 coding region and the $3^{\prime}$ flanking region were ligated with the fungal transformation vector pCW02052 (described below) digested with BamHI and NotI.

To make the fungal transformation vector pCW02052, a ClaI site was added $5^{\prime}$ of the start codon of the $h p h$ gene in pCX62 (Zhao et al. 2004) using PCR with the primer pair CX62+ClaF and CX62+ClaR and pCX62 as the template. The 0.6-kb PCR product was cloned into the pGEM-T Easy vector (Promega Corp., Madison, WI, U.S.A.) to yield pCW02051. To make pCW02052, a 320-bp FseI-ClaI fragment from pDH33 (Smith et al. 1990) containing a minimal glaA promoter and approximately $100 \mathrm{bp}$ of additional 5' untranslated sequence (Fowler et al. 1990), a ClaI-SphI fragment from pCW02051 containing 600 bp of the amino terminal region of $h p h$, and a 3.4-kb SphI-FseI fragment of pCX62 containing the remainder of the coding region of the $h p h$ gene and the plasmid backbone were ligated together. The regions flanking the $h p h$ gene to target homologous recombination at the FoPDA1 locus ranged from approximately 960 to $1,300 \mathrm{bp}$ for the $5^{\prime}$ flanking region and approximately $600 \mathrm{bp}$ to $1,800 \mathrm{bp}$ for the $3^{\prime}$ flanking region.

\section{Fungal transformation and screening for pda activity.}

$F$. oxysporum and N. haematococca protoplasts for transformation were generated with Kitalase (Wako Pure Chemical In- 
dustries, Ltd., Osaka, Japan) and Lytizyme (Karlan Research Products Corporation, Cottonwood, AZ, U.S.A.), as previously described (Coleman et al. 2011).

Transformation was carried out as described by Coleman and associates (2011), except that $F$. oxysporum and $N$. haematococca transformants were selected on potato dextrose agar with hygromycin B (Calbiochem, La Jolla, CA, U.S.A.) at 70 or $60 \mu \mathrm{g} / \mathrm{ml}$, respectively. Hygromycin-resistant colonies were transferred to plates containing M-100 medium (Stevens 1974) with hygromycin at $100 \mu \mathrm{g} / \mathrm{ml}$, or hygromycin at $70 \mu \mathrm{g} / \mathrm{ml}$ for $F$. oxysporum or $N$. haematococca transformants. Transformants were assessed for their ability to demethylate pisatin in a vial assay as described by Mackintosh and associates (1989) using $0.25 \mathrm{ml}$ of peptone-glucose agar medium (VanEtten et al. 1980) supplemented with $\left[{ }^{14} \mathrm{C}\right]$ pisatin $(31 \mu \mathrm{g}$ of pisatin per $10,000 \mathrm{dpm}$ per $5 \mu \mathrm{l}$ of DMSO per milliliter of medium). Scintillation fluid ( $4 \mathrm{ml} 0.5 \%$ PPO in toluene) was added to terminate the assay after $96 \mathrm{~h}$ and to extract the remaining $\left[{ }^{14} \mathrm{C}\right]$ pisatin. The amount of $\left[{ }^{14} \mathrm{C}\right]$ was measured in a Beckman Instruments model LS 6000SC scintillation counter.

\section{Pea pathogenicity assay and statistical analysis.}

Virulence was assessed using the test tube assay (VanEtten et al. 1980) as modified by Wasmann and VanEtten (1996). Virulence was quantified by measuring the lengths of lesions produced by each isolate on the hypocotyls of pea seedlings 6 to 8 days after inoculation. Unless noted otherwise, each test isolate was inoculated onto eight seedlings per experiment. In each trial, the mean lesion length was used as a measure of virulence. In addition to the test isolates, trials to assess the virulence of transformants included the $\mathrm{Pda}^{-}$parent isolate. The Student's $t$ test was used in pairwise comparisons across trials.

\section{Phylogenetic analysis.}

The translation elongation factor (EF)- $1 \alpha$ of $F$. oxysporum $\mathrm{f}$. sp. phaseoli was amplified by PCR using the primers EF-1 and EF-2 and sequenced. Phylogenetic analysis was conducted using MacVector and previously obtained EF- $1 \alpha$ sequences (Temporini and VanEtten 2004). Analyses of the PDA genes and pseudogenes from the other formae speciales were performed using the full length of DNA corresponding to the coding region of the functional FoPDA1 gene in F. oxysporum f. sp. pisi. Alignments were conducted using ClustalW, and phylogenetic neighbor-joining trees generated with 1,000 bootstraps.

\section{ACKNOWLEDGMENTS}

We thank the John Innes Institute for providing the isolate (J1 2) of $F$. oxysporum f. sp. pisi and Kerry O'Donnell for providing many of the other F. oxysporum isolates used in this study. This work was supported by the National Science Foundation (grant number MCB-0641808 to H. D. VanEtten).

\section{LITERATURE CITED}

Baayen, R. P., O’Donnell, K., Bonants, P. J. M., Cigelnik, E., Kroon, L. P. N. M., Roebroeck, E. J. A., and Waalwijk, C. 2000. Gene genealogies and AFLP analyses in the Fusarium oxysporum complex identify monophyletic and nonmonophyletic formae speciales causing wilt and rot diseases. Phytopathology 90:891-900.

Ciuffetti, L. M., and VanEtten, H. D. 1996. Virulence of a pisatin-deficient Nectria haematococca MPVI isolate is increased by transformation with a pisatin demethylase gene. Mol. Plant-Microbe Interact. 9:787792.

Coleman, J. J., White, G. J., Rodriguez-Carres, M., and VanEtten, H. D. 2011. An ABC transporter and a cytochrome P450 of Nectria haematococca MPVI are virulence factors on pea and are the major tolerance mechanisms to the phytoalexin pisatin. Mol. Plant-Microbe Interact. 24:368-374
Cruickshank, I. A. M. 1962. Studies on phytoalexins. IV. The antimicrobial spectrum of pisatin. Aust. J. Biol. Sci. 15:147-159.

Delserone, L. M., McCluskey, K., Matthews, D. E., and VanEtten, H. D. 1999. Pisatin demethylation by fungal pathogens and nonpathogens of pea: Association with pisatin tolerance and virulence. Physiol. Mol. Plant Pathol. 55:317-326.

Di Pietro, A., Madrid, M. P., Caracuel, Z., Delgado-Jarana, J., and Roncero, M. I. G. 2003. Fusarium oxysporum: Exploring the molecular arsenal of a vascular wilt fungus. Mol. Plant Pathol. 4:315-325.

Fowler, T., Berka, R. M., and Ward, M. 1990. Regulation of the glaA gene of Aspergillus niger. Curr. Genet. 18:537-545.

Funnell, D. L., and VanEtten, H. D. 2002. Pisatin demethylase genes are on dispensable chromosomes while genes for pathogenicity on carrot and ripe tomato are on other chromosomes in Nectria haematococca. Mol. Plant-Microbe Interact. 15:840-846.

Funnell, D. L., Matthews, P. S., and VanEtten, H. D. 2002. Identification of new pisatin demethylase genes (PDA5 and PDA7) in Nectria haematococca and non-Mendelian segregation of pisatin demethylating ability and virulence on pea due to loss of chromosomal elements. Fungal Genet. Biol. 37:121-133.

George, H. L. 1998. Biochemical characterization of pisatin demethylases from fungal pea pathogens. Ph.D. thesis, University of Arizona.

George, H. L., and VanEtten, H. D. 2001. Characterization of pisatininducible cytochrome P450s in fungal pathogens of pea that detoxify the pea phytoalexin pisatin. Fungal Genet. Biol. 33:37-48.

George, H. L., Hirsch, K., and VanEtten, H. D. 1998. Biochemical properties of the products of cytochrome P450 genes (PDA) encoding pisatin demethylase activity in Nectria haematococca. Arch. Microbiol. 170:147-154

Gordon, T. R., and Martyn, R. D. 1997. The evolutionary biology of Fusarium oxysporum. Annu. Rev. Phytopathol. 35:111-128.

Haglund, W. A., and Kraft, J. M. 1979. Fusarium oxysporum f. sp. pisi, race 6: Occurrence and distribution. Phytopathology 69:818-820.

Han, Y., Liu, X., Benny, U., Kistler H. C., and VanEtten, H. D. 2001. Genes determining pathogenicity to pea are clustered on a supernumerary chromosome in the fungal plant pathogen Nectria haematococca. Plant J. 25:305-314.

Kerstin, S., Bodker, L., and Rosendahl, S. 2002. Population structure and pathogenicity of members of the Fusarium oxysporum complex isolated from soil and root necrosis of pea (Pisum sativum L.). FEMS (Fed. Eur. Microbiol. Soc.) Microbiol. Ecol. 42:367-374.

Khan, R., and Straney, D. C. 1999. Regulatory signals influencing expression of the PDA1 gene of Nectria haematococca MPVI in culture and during pathogenesis of pea. Mol. Plant-Microbe Interact. 12:733742.

Khan, R., Tan, R., Mariscal, A. G., and Straney, D. 2003. A binuclear zinc transcription factor binds the host isoflavonoid-responsive element in a fungal cytochrome p450 gene responsible for detoxification. Mol. Microbiol. 49:117-130.

Kistler, H. C., and VanEtten, H. D. 1984a. Three non-allelic genes for pisatin demethylation in the fungus Nectria haematococca. J. Gen. Microbiol. 130:2595-2603.

Kupfer, D. M., Drabenstot, S. D., Buchanan, K. L., Lai, H., Zhu, H., Dyer, D. W., Roe, B. A., and Murphy, J. W. 2004. Introns and splicing elements of five diverse fungi. Eukaryot. Cell 3:1088-1100.

Liu, X. G., Inlow, M., and VanEtten, H. D. 2003. Expression profile of pea pathogenicity $(P E P)$ genes in vivo and in vitro, characterization of the flanking regions of the $P E P$ cluster and evidence that the $P E P$ cluster region resulted from horizontal gene transfer in the fungal pathogen Nectria haematococca. Curr. Genet. 44:95-103.

Livak, K., and Schmittgen, T. 2001. Analysis of relative gene expression data using real-time quantitative PCR and the $2^{-\Delta \Delta \mathrm{Ct}}$ method. Methods 25:402-408.

Ma, L.-J., van der Does, H. C., Borkovich, K. A., Coleman, J. J., Daboussi, M.-J., Di Pietro, A., Dufresne, M., Freitag, M., Grabherr, M. Henrissat, B., Houterman, P. M., Kang, S., Shim, W.-B., Woloshuk, C., Xie, X., Xu, J.-R., Antoniw, J., Baker, S. E., Bluhm, B. H., Breakspear, A., Brown, D. W., Butchko, R. A. E., Chapman, S., Coulson, R., Coutinho, P. M., Danchin, E. G. J., Diener, A., Gale, L. R., Gardnier, D. M., Goff, S., Hammond-Kosack, K. E., Hilburn, K., Hua-Van, A., Jonkers, W., Kazan, K., Kodira, C. D., Koehrsen, M., Kumar, L., Lee, Y.-H., Li, L., Manners, J. M., Miranda-Saavedra, D., Mukherjee, M., Park, G., Park, J., Park, S.-Y., Proctor, R. H., Regev, A., Ruiz-Roldan, M. C., Sain, D., Sakthikumar, S., Sykes, S., Schwartz, D. C., Turgeon, B. G., Wapinski, I., Yoder, O., Young, S., Zeng, Q., Zhou, S., Galagan, J., Cuomo, C. A., Kistler, H. C., and Rep, M. 2010. Comparative genomics reveals mobile pathogenicity chromosomes in Fusarium. Nature 464:367-373.

Mackintosh, S. F., Matthews, D. E., and VanEtten, H. D. 1989. Two additional genes for pisatin demethylation and their relationship to the 
pathogenicity of Nectria haematococca on pea. Mol. Plant-Microbe Interact. 4:341-349.

Maloney, A. P., and VanEtten, H. D. 1994. A gene from the fungal plant pathogen Nectria haematococca that encodes the phytoalexin-detoxifying enzyme defines a new cytochrome P450 family. Mol. Gen. Genet. 243:506-514.

Miao, V. P. W., and VanEtten, H. D. 1992. Three genes for metabolism of the phytoalexin maackiain in the plant pathogen Nectria haematococca: Meiotic instability and relationship to a new gene for pisatin demethylase. Appl. Environ. Microbiol. 58:801-808.

Miao, V. P. W., Matthews, D. E., and VanEtten, H. D. 1991. Identification and chromosomal locations of a family of cytochrome P-450 genes for pisatin detoxification in the fungus Nectria haematococca. Mol. Gen. Genet. 226:214-223.

Michielse, C. B., and Rep, M. 2009. Pathogen profile update: Fusarium oxysporum. Mol. Plant Pathol. 10:311-324.

Morrissey, J. P., and Osbourn, A. E. 1999. Fungal resistance to plant antibiotics as a mechanism of pathogenesis. Microbiol. Mol. Biol. Rev. 63:708-724

O’Donnell, K., Kistler, H. C., Cigelnik, E., and Ploetz, R. C. 1998. Multiply evolutionary origins of the fungus causing Panama disease of banana: Concordant evidence from nuclear and mitochondrial gene genealogies. Proc. Natl. Acad. Sci. U.S.A. 95:2044-2049.

O’Donnell, K., Gueidan, C., Sink, S., Johnston, P. R., Crous, P. W., Glenn, A., Riley, R., Zitomer, N. C., Colyer, P., Waalwijk, C., van der Lee, T., Moretti, A., Kang, S., Kim, H.-S., Geiser, D. M., Juba, J. H., Baayen, R. P., Cromey, M. G., Bithell, S., Sutton, D. A., Skovgaard, K., Ploetz, R., Kistler, H. C., Elliott, M., Davis, M., and Sarver, B. A. J. 2009. A twolocus DNA sequence database for typing plant and human pathogens within the Fusarium oxysporum species complex. Fungal Genet. Biol. 46:936-948.

Orbach, M. J., Vollrath, D., Davis, R. W., and Yanofsky, C. 1988. An electrophoretic karyotype of Neurospora crassa. Mol. Cell. Biol. 8:14691473.

Reimmann, C., and VanEtten, H. D. 1994. Cloning and characterization of the PDA6-1 gene encoding a cytochrome P-450 which detoxifies the phytoalexin pisatin from garden pea. Gene 146:221-226.

Sambrook, J., and Russell, D. W. 2001. Molecular Cloning: A Laboratory
Manual, third ed. Cold Spring Harbor Laboratory Press, Cold Spring Harbor, NY, U.S.A..

Smith, T. L., Gaskell, J., Berka, R. M., Yang, M., Henner, D. J., and Cullen, D. 1990. The promoter of the glucoamylase-encoding gene of Aspergillus niger functions in Ustilago maydis. Gene 88:259-262.

Stevens, R. B. 1974. Mycology Guidebook. University of Washington Press, Seattle.

Straney, D. C., and VanEtten, H. D. 1994. Characterization of the PDA promoter of Nectria haematococca and identification of a region that binds a pisatin-responsive DNA binding factor. Mol. Plant-Microbe Interact. 7:256-266.

Temporini, E. D., and VanEtten, H. D. 2002. Distribution of the pea pathogenicity genes in the fungus Nectria haematococca mating population VI. Curr. Genet. 41:107-114.

Temporini, E. D., and VanEtten, H. D. 2004. An analysis of the phylogenetic distribution of the pea pathogenicity genes of Nectria haematococca MPVI supports the hypothesis of their origin by horizontal transfer and uncovers a potentially new pathogen of garden pea: Neocosmospora boniensis. Curr. Genet. 46:29-36.

VanEtten, H. D., and Barz, W. 1981. Expression of pisatin demethylating ability in Nectria haematococca. Arch. Microbiol. 129:56-60.

VanEtten, H. D., Matthews, P. S., Tegtmeier, K. J., Dietert, M. F., and Stein, J. I. 1980. The association of pisatin tolerance and demethylation with virulence on pea in Nectria haematococca. Physiol. Plant Pathol. 16:257-269.

VanEtten, H. D., Matthews, D. E., and Matthews, P. S. 1989. Phytoalexin detoxification: Importance for pathogenicity and practical implications. Annu. Rev. Phytopathol. 27:143-164.

VanEtten, H. D., Temporini, E., and Wasmann, C. 2001. Phytoalexin (and phytoanticipin) tolerance as a virulence trait: Why is it not required by all pathogens? Physiol. Mol. Plant Pathol. 59:83-93.

Wasmann, C. C., and VanEtten, H. D. 1996. Transformation-mediated chromosome loss and disruption of a gene for pisatin demethylase decrease the virulence of Nectria haematococca on pea. Mol. Plant-Microbe Interact. 9:793-803.

Zhao, X., Xue, C., Kim, Y., and Xu, J.-R. 2004. A ligation-PCR approach for generating gene replacement constructs in Magnaporthe grisea. Fungal Genet. Newl. 51:17-18. 